Med. Microbiol. Immunol. 163, 277 (1977)

\title{
Medical Microbiology and immunology
}

(C) by Springer-Verlag 1977

\section{Erratum}

Synthetic Disaccharide - Protein Antigens for Production of Specific 04 and 09 Antisera for Immunofluorescence Diagnosis of Salmonella

Med. Microbiol. Immunol. 163, 1-11 (1977)

B. Svenungsson and A.A. Lindberg

Department of Bacteriology, National Bacteriological Laboratory, S-105 21 Stockholm, Sweden

The two complete sentences in lines 9,10 , and 11 on page 6 are incorrect and should be deleted. The one sentence below should be inserted in their place:

Four of the Yersinia pseudotuberculosis strains gave a strong positive fluorescence with the anti AM-BSA (0 4) serum, one strain stained with the anti TM-BSA (0 9) serum. 